\title{
Universal Health Care and political economy, neoliberalism and effects of COVID-19 - a view of systems and complexity
}

\author{
Chris Peterson $^{1}$ and Christine Walker ${ }^{2}$ \\ ${ }^{1}$ La Trobe University \\ ${ }^{2}$ University of Melbourne VCCC
}

October 4, 2021

\begin{abstract}
Sturmberg and Martin's application of systems and complexity theory to understanding Universal Health Care (UHC) and Primary Health Care (PHC) is evaluated in the light of the influence of political economy on health systems. Further the role that neoliberal approaches to governance have had in creating increased inequities is seen as a key challenge for UHC. COVID-19 has emphasized long standing discrepancies in health and these disadvantages require government will and cooperation together with adequate social services to redress these discrepancies in UHC.
\end{abstract}

\section{Hosted file}

Political economy of UHC and COVID 19_Sept 20 Manuscript.docx available at https: //authorea.com/users/332254/articles/540351-universal-health-care-and-political-economyneoliberalism-and-effects-of-covid-19-a-view-of-systems-and-complexity 